\title{
Carbon Sequestration and Nitrogen Transformation in Soil Cooperated with Organic Composts and Biochar during Corn (Zea mays) Cultivation
}

\author{
Joung Du Shin \\ Department of Climate Change \& Ecology, National Academy of Agricultural Science, RDA, Wanju, Republic of Korea \\ Email: jdshin1@korea.kr
}

Received 17 August 2015; accepted 18 October 2015; published 22 October 2015

Copyright (C) 2015 by author and Scientific Research Publishing Inc.

This work is licensed under the Creative Commons Attribution International License (CC BY). http://creativecommons.org/licenses/by/4.0/

(c) (i) Open Access

\begin{abstract}
Background: Objectives of this study were to investigate changes of soil carbon contents and to evaluate $\mathbf{N}$ mineralization and nitrification rates in soils cooperated with organic composts and biochar during the $2^{\text {nd }}$ year corn cultivation. Methods and Results: For the experiment, the soil texture used in this study was clay loam. Application rates of chemical fertilizer were 480-150$260 \mathrm{~kg} / \mathrm{ha}\left(\mathrm{N}-\mathrm{P}_{2} \mathrm{O}_{5}-\mathrm{K}_{2} \mathrm{O}\right)$ as recommended amount after soil test. Biochar application was $0.2 \%$ to soil weight. The soil samples were periodically taken at every 15-day interval during corn cultivation periods. The treatments were consisted of cow compost (CC), pig compost (PC), swine digestate from aerobic digestion system (AD), and their biochar cooperation. TC contents in treatments cooperated with biochar at harvesting stages were ranged from $0.96 \%$ to $1.24 \%$, and its CC applied plot was highest at $\mathbf{1 . 2 4 \%}$. It was observed that TC contents with biochar treatments were higher than the compost treatment only. Therefore, it was observed to be carbon sequestration into corn field cooperated with biochar. For nitrogen transformation in soil cooperated with organic composts and biochar, net mineralization rates were dramatically decreased at 44 days after sowing, but nitrification rates were abruptly increased at 73 days after sowing. For $\mathrm{N}$ mineralization and nitrification rates, it was shown that they were generally low in the soil cooperated with biochar as compared to the only application plots of different organic composts. Also, it was observed to be highest in the application plot of pig compost manure. Conclusion: Overall, application of biochar in the cropland could be an important role for mitigation of greenhouse gas as well as carbon sequestration.
\end{abstract}

\section{Keywords}

Biochar, Carbon Sequestration, Nitrogen Mineralization and Nitrification, Organic Composts 


\section{Introduction}

Biochar is a charcoal-like material produced by thermo-chemical pyrolysis of biomass materials. It is being considered as a potentially significant means of storing carbon for long periods to mitigate greenhouse gases [1]. Much of the interest in biochar comes from studies of Amazonian soils that appear to have been amended with biochar, with significant improvements in soil quality and positive effects on crop production [2]. Biochar represents a stable form of carbon and thus provides an intriguing potential carbon storage strategy as soil amendment [3].

Biochar may improve soil physical properties as increase of soil pH and cation exchange capacity (CEC), and enhancement of nutrient retention. This has provided the incentive to study the effects of biochar applications on soil N cycling [4]-[7]. Number of studies has reported that adding biochar to soils may increase net nitrification rate [8] and alter $\mathrm{N}$ availability for crops [9]. Biochar addition has altered $\mathrm{N}$ transformation following the application of $\mathrm{N}$ containing substances such as bovine urine, swine manure, green waste compost and bio-solid [10][12]. The interaction between biochar and soil $\mathrm{N}$ cycle is acknowledged, and there are several comprehensive reviews recently published on this topic [13] [14]. Most of the $\mathrm{N}$ fertilizer applied into agricultural soils is in the form of $\mathrm{NH}_{4}^{+}$or $\mathrm{NH}_{4}^{+}$-based compounds (e.g., urea or ammonium sulfate). Once added into soils, $\mathrm{NH}_{4}^{+}$is rapidly converted into $\mathrm{NO}_{3}^{-}$via nitrification, which is vulnerable to leaching, or loss as $\mathrm{N}_{2} \mathrm{O}$ or $\mathrm{N}_{2}$ because of denitrification, resulting in $45 \%-60 \% \mathrm{~N}$ loss [15]. If nitrification is reduced or inhibited in agricultural soils, plants may take more available $\mathrm{NH}_{4}^{+}$from soils, thereby improving $\mathrm{N}$ use efficiency and mitigating the environmental impacts caused by $\mathrm{N}$ loss [15]. The most common practice currently being considered for inhibiting nitrification is the addition of nitrification inhibitors into soils [15]. Biochar may be an ideal choice to achieve the desired goals due to its multiple benefits in soils. Fertilizers in combination with biochar have been proposed for improving temporal synchrony between crop $\mathrm{N}$ demand and soil $\mathrm{N}$ availability, enhancing $\mathrm{N}$ use efficiency and reducing environmental impacts. However, the mechanism by which biochar influences such processes is not well understood. The reduction in $\mathrm{N}_{2} \mathrm{O}$ emissions after biochar soil amendment was first reported in a greenhouse experiment by Rondon et al. [16]. They found that $\mathrm{N}_{2} \mathrm{O}$ emissions were decreased by up to $50 \%$ for soybean and by up to $80 \%$ for grass growing in a low fertility oxisol from the Colombian savanna. Since then, the interest in biochar as a $\mathrm{N}_{2} \mathrm{O}$ mitigation strategy for agricultural soils has been continuously increasing, and the number of studies evaluating $\mathrm{N}_{2} \mathrm{O}$ emissions from biochar treated soils has risen exponentially.

Therefore, these experiments were conducted to investigate the changes of carbon contents and to evaluate $\mathrm{N}$ mineralization and nitrification rates in soil cooperated with different composts and biochar during the $2^{\text {nd }}$ year corn cultivation periods.

\section{Materials and Methods}

The corn variety used in this experiment was Miback $2 \mathrm{Ho}$, and planting distance was $30 \times 60 \mathrm{~cm}$. Soil texture was clay loam. The treatments were consisted of cow compost (CC), pig compost (PC), swine digestate from aerobic digestion system (AD), and their biochar cooperation as same as $1^{\text {st }}$ year corn cultivation. Fertilizers were applied with 480-150-260 kg/ha $\left(\mathrm{N}_{-} \mathrm{P}_{2} \mathrm{O}_{5}-\mathrm{K}_{2} \mathrm{O}\right)$ as whole basal application for $\mathrm{P}_{2} \mathrm{O}_{5}$ and $\mathrm{K}_{2} \mathrm{O}$, and it was especially applied half for basal at 3 day before sowing and half for additional application for nitrogen at 44 days after sowing, based on chemical properties of soil before experiment. CC and PC were applied with 25,000 and $5500 \mathrm{~kg} / \mathrm{ha}$ into soil, respectively. AD was applied with 100 ton/ha in soil that was $16 \%$ of water holding capacity. Application rate of biochar for $2^{\text {nd }}$ year corn cultivation was $0.2 \%$ of soil weight $(1,300,000 \mathrm{~kg} / \mathrm{ha}) \mathrm{in}$ case of being 1.3 of bulk density and $10 \mathrm{~cm}$ of soil depth. Biochar from rice hull was purchased from local farming cooperative society. Physiochemical properties of soil and biochar used were presented in Table 1 and Table 2. Based on soil physiochemical properties, application rates of fertilizer were decided by its recommended application amount after soil test.

Soil samples were periodically collected for every 15 day interval after treatment during corn cultivation periods. The samples were dried and passed through $2 \mathrm{~mm}$ sieve, and then stored in the refrigerator $\left(4^{\circ} \mathrm{C}\right)$ until analyzing the soil chemical properties.

Analytical chemical properties of soil and biochar were analyzed total carbon (TC) and total organic carbon (TOC) by TOC analyzer (Elementar Vario EL II, Germany). Its combustion temperature was $950^{\circ} \mathrm{C}$ and $\mathrm{WO}_{3}$ was used as the catalyst. Thus TC contents were obtained. Soil extract solutions with $2 \mathrm{M} \mathrm{KCl} \mathrm{(1:5,} \mathrm{soil:extrac-}$ tant ratio) were analyzed $\mathrm{NH}_{4}-\mathrm{N}$ and $\mathrm{NO}_{3}-\mathrm{N}$ contents by Auto Analyzer Technician II. 
Table 1. Physiochemical properties of soil used in this study.

\begin{tabular}{cccccccccc}
\hline Soil Texture & $\begin{array}{c}\mathrm{pH} \\
(1: 5)\end{array}$ & $\begin{array}{c}\mathrm{EC} \\
(\mathrm{dS} / \mathrm{m})\end{array}$ & $\begin{array}{c}\mathrm{OM} \\
(\mathrm{g} / \mathrm{kg})\end{array}$ & $\begin{array}{c}\mathrm{T}-\mathrm{C} \\
(\%)\end{array}$ & $\begin{array}{c}\text { Av. } \mathrm{P}_{2} \mathrm{O}_{5} \\
(\mathrm{mg} / \mathrm{kg})\end{array}$ & \multicolumn{3}{c}{$\mathrm{CEC}\left(\mathrm{cmol}^{+} / \mathrm{kg}\right)$} \\
\cline { 6 - 9 }
\end{tabular}

Table 2. Characteristics of biochar used in this study.

\begin{tabular}{|c|c|c|c|c|c|}
\hline $\mathrm{pH}$ & EC & TC & TOC & TIC & $\mathrm{TN}$ \\
\hline$(1: 20)$ & $\mathrm{dS} / \mathrm{m}$ & & 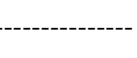 & ------- & \\
\hline 10.7 & 13.3 & $44.3 \pm 2.4$ & $38.9 \pm 1.0$ & $5.4 \pm 2.8$ & $0.07 \pm 0.1$ \\
\hline
\end{tabular}

For effects of soil nitrogen transformation to biochar application, soil nitrogen mineralization was estimated as below equation;

$$
\text { Nitrogen mineralization }=\sum_{i}^{n}\left(x_{n}-x_{i}\right)
$$

where, $n=$ number of days after $i$; $i=$ zero days of soil sampling after sowing; $x=$ concentration of $\mathrm{NH}_{4}-\mathrm{N}+$ $\mathrm{NO}_{3}-\mathrm{N}(\mathrm{mg} / \mathrm{kg})$.

Also soil nitrogen nitrification was estimated as below equation;

$$
\text { Nitrogen nitrification }=\sum_{i}^{n}\left(x_{n}-x_{i}\right)
$$

where, $n=$ number of days after $i ; i=$ zero days of soil sampling after sowing; $x=$ concentration of $\mathrm{NO}_{3}-\mathrm{N}$ $(\mathrm{mg} / \mathrm{kg})$.

\section{Results and Discussions}

Soil carbon (C) is a major determinant of sustainability of agricultural system. Changes can occur in both total and active, or labile, C pool. Also soil carbon is major factor of carbon sequestration for mitigation techniques of greenhouse gases. For TC and TN contents of input materials, its biochar was higher at 1.6 fold than CC. Biochar could be mostly organic carbon as well as their CC and PC due to carbon fractions (Table 3). However, biochar could be mostly non-degradable organic carbon on the contrary of its CC and PC because it resists microbial decomposition in the soil for a much longer time than regular biomass [17]. Also, biochar's carbon bonds don't break down, and remain in soil for centuries [18]. Lowest TC content was observed to be its PC.

Changes of TC contents in the soil applied with different organic composts and biochar during corn cultivation periods were described in Figure 1. For soil carbon sequestration, effects of biochar were TC contents for differences between the compost treatment only and the same compost treated plot cooperated with biochar after harvest. It was observed that TC contents were decreased with days after sowing, and their peaks were 15 days after sowing (Figure 1). In the other hand, Shin et al. (2014) indicated that TC contents were increased with days after sowing through harvesting periods [19]. This difference might be attributed to plant growth's aspect whether it is good or bad due to utilizing ability of soil carbon (Figure 1). TC contents in treatments cooperated with biochar at harvesting stages were ranged from $0.96 \%$ to $1.24 \%$, and its CC applied plot was highest at $1.24 \%$. It was observed that TC contents with biochar treatments were higher than the compost treatment only. Therefore, it was observed to be carbon sequestration in corn field cooperated with application of biochar.

Soil nitrogen mineralization rate was estimated by using Equation (1). Mineralization rates in the organic compost treatment plots were higher than the cooperated biochar except 59 days and 93 days after sowing in the $\mathrm{AD}$ and PC cooperated with biochar, respectively, through corn cultivation periods (Figure 2). It was shown that $\mathrm{N}$ net mineralization was decreased at 44 days after sowing and promptly increased up to 73 days after sowing regardless of organic compost treatments.

Soil nitrogen nitrification rate was calculated by using Equation (2). For nitrification rates in the soil cooperated 
Table 3. Total carbon and nitrogen contents of input materials.

\begin{tabular}{ccc}
\hline Input materials* & T-C (\%) & T-N (\%) \\
\hline CC & $27.1 \pm 0.2$ & 1.1 \\
PC & $41.5 \pm 0.3$ & 1.5 \\
Rice hull & $36.47 \pm 0.4$ & $0.37 \pm 0.03$ \\
Biochar based on rice hull & $44.3 \pm 0.1$ & $0.07 \pm 0.1$ \\
\hline
\end{tabular}

*CC: cow compost; PC: pig compost.

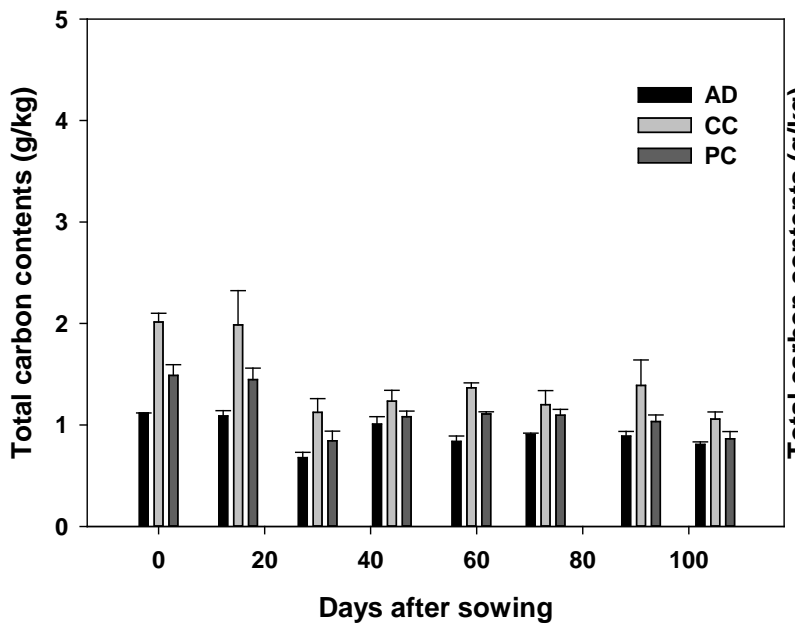

(a)

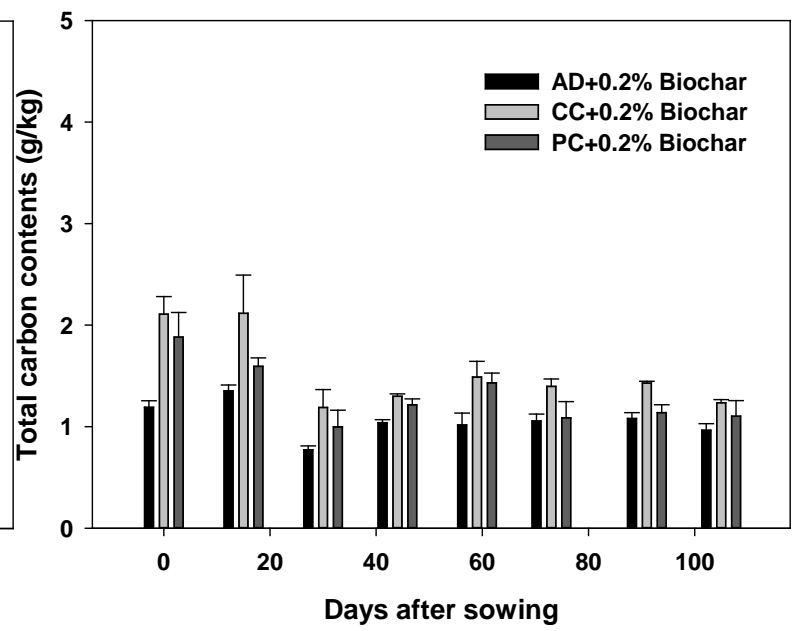

(b)

Figure 1. Changes of total carbon contents in the soil applied with different organic composts and their cooperated with biochar during corn cultivation periods (AD: aerobic digestate, CC: cow compost, PC: pig compost).

with biochar during corn cultivation, it was only highest in PC during corn cultivation periods (Figure 3).

For nitrogen transformation in soil cooperated with organic composts and their cooperated with biochar, net mineralization rates were dramatically decreased at 44 days after sowing, but nitrification rates were abruptly increased at 73 days after sowing (Figure 2 and Figure 3). It was observed that mineralization and nitrification rates were highest in the application plot of PC. Overall, nitrogen mineralization and nitrification rates in the application plots of different organic composts were higher than their cooperated with biochar application plots. This result was coincided with Shin's previous research with application of different organic compost and their cooperated with biochar in corn field for carbon sequestration [20]. Biochar application might be inhibitor for mineralization and nitrification rates in the corn field.

While there is recognized lack of literature on the interactions among biochar, soil biota and N cycling [13], evidence is emerging that biochar may limit the availability of $\mathrm{N}$ in soil, thus reducing substrate availability for production of $\mathrm{N}_{2} \mathrm{O}$. However, our observations differ from those made by Deluca et al. [8], who found that adding biochar to soils may increase net nitrification rate. There are losses of nitrogen from soil in ways other than leaching and crop removal. Gaseous occur primarily as nitrous oxide $\left(\mathrm{N}_{2} \mathrm{O}\right)$ and dinitrogen $\left(\mathrm{N}_{2}\right)$ during reductive (denitrification) and oxidative (nitrification) process. Therefore, $\mathrm{N}_{2} \mathrm{O}$ emission in the cropland applied with biochar could be reduced because $\mathrm{N}$ mineralization and nitrification rates were inhibited for biochar's absorption capacity of $\mathrm{NH}_{4}-\mathrm{N}$ in the soil [21]. Overall, Application of biochar in the cropland could be important role for mitigation of greenhouse gas as well as carbon sequestration.

\section{Summary}

For carbon storage in soil, TC contents with biochar treatments were higher than the compost treatment only. Therefore, it was observed to be carbon sequestration in corn field cooperated with application of biochar. For $\mathrm{N}$ mineralization and nitrification rates, it was shown that they were generally low in the soil cooperated with 


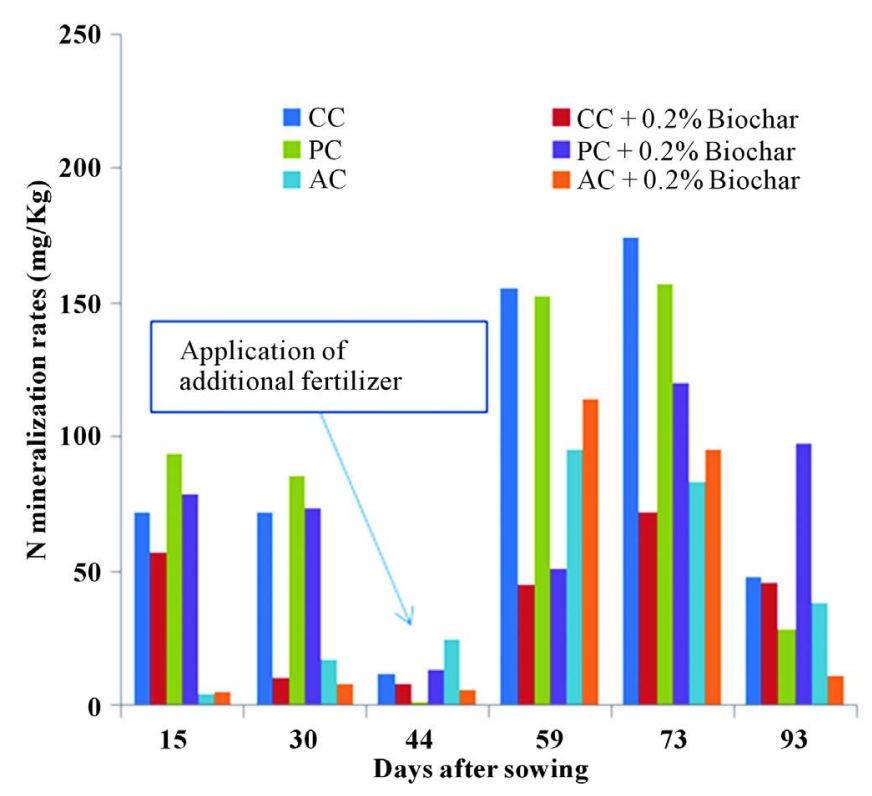

Figure 2. Changes of nitrogen mineralization in soil applied with different composts and their cooperated with biochar during corn cultivation periods (AD: aerobic digestate, CC: cow compost, PC: pig compost).

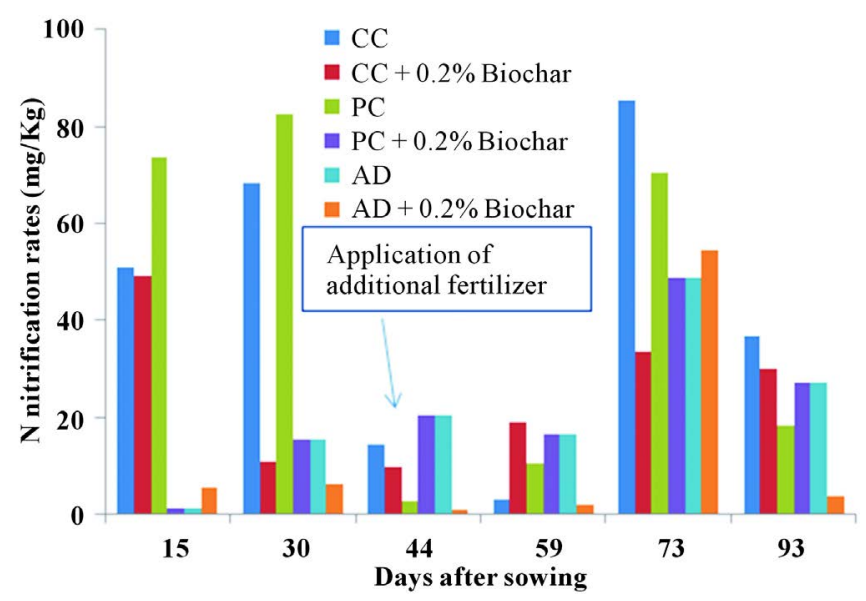

Figure 3. Changes of nitrogen nitrification in soil applied with organic composts and their cooperated with biochar during corn cultivation periods (AD: aerobic digestate, CC: cow compost, PC: pig compost).

biochar as compared to the only application plots of different organic composts. Overall, application of biochar in the cropland could be an important role for mitigation of greenhouse gas as well as carbon sequestration.

\section{Acknowledgements}

This study was carried with the support of "Research Program for Agricultural Science \& Technology Development (Project No. PJ 010920)”, National Academy of Agricultural Science, Rural Development Administration, Republic of Korea.

\section{References}

[1] Laird, A.D. (2008) The Charcoal Vision: A Win-Win-Win Scenario for Simultaneously Producing Bioenergy, Perma- 
nently Sequestering Carbon, While Improving Soil and Water Quality. Agronomy Journal, 100, 178-184. http://dx.doi.org/10.2134/agrojnl2007.0161

[2] Lehmann, J., Kern, D.C., Glaser, B. and Woods, W.I. (2004) Management. Kluwer Academic Publishers, New York.

[3] Mathews, J.A. (2008) Carbon-Negative Biofuels. Energy Policy, 36, 940-945. http://dx.doi.org/10.1016/j.enpol.2007.11.029

[4] Ding, Y., Liu, Y., Wu, W., Shi, D., Yang, M. and Zhong, Z. (2010) Evaluation of Biochar Effects on Nitrogen Retention and Leaching in Multi-Layered Soil Columns. Water, Air, \& Soil Pollution, 213, 448-453. http://dx.doi.org/10.1007/s11270-010-0366-4

[5] Lehmann, J., Pereira da Silva, J., Steiner, C., Nehls, T., Zech, W. and Glaser, B. (2003) Nutrient Availability and Leaching in an Archaeological Anthrosol and a Ferralsol of the Central Amazon Basin: Fertilizer, Manure and Charcoal Amendments. Plant Soil, 249, 343-357. http://dx.doi.org/10.1023/A:1022833116184

[6] Steiner, C., Das, K., Melear, N. and Lakly, D. (2010) Reducing Nitrogen Loss during Poultry Litter Composting Using Biochar. Journal of Environmental Quality, 39, 1236-1242. http://dx.doi.org/10.2134/jeq2009.0337

[7] Taghizadeh-Toosi, A., Clough, T.J., Sherlock, R.R. and Condron, L.M. (2012) Biochar Adsorbed Ammonia Is Bioavailable. Plant Soil, 350, 57-69. http://dx.doi.org/10.1007/s11104-011-0870-3

[8] Deluca, T.H., Mackenzie, M.D., Gundale, M.J. and Holben, W.E. (2006) Wieldfire Produced Charcoal Directly Influences Nitrogen Cycling in Ponderosa Pine Forests. Soil Science Society of America Journal, 70, 448-453. http://dx.doi.org/10.2136/sssaj2005.0096

[9] Steiner, C., Glaser, B., Teixeira, W.G., Lehmann, J., Blum, W.E.H. and Zech, W. (2008) Nitrogen Retention and Plant Uptake on a Highly Weathered Central Amazonian Ferralsol Amended with Compost and Charcoal. Journal of Plant Nutrition and Soil Science, 171, 893-899. http://dx.doi.org/10.1002/jpln.200625199

[10] Clough, T., Bertram, J., Ray, J., Condron, L., O’Callaghan, M., Sherlock, R. and Wells, N. (2010) Unweathered Wood Bio-Char Impact on Nitrous Oxide Emissions from a Bovine-Urine Amended Pasture Soil. Soil Science Society of America Journal, 74, 852. http://dx.doi.org/10.2136/sssaj2009.0185

[11] Laird, D., Fleming, P., Wang, B., Horton, R. and Karlen, D. (2010) Biochar Impact on Nutrient Leaching from a Midwestern Agricultural Soil. Geoderma, 158, 436-442. http://dx.doi.org/10.1016/j.geoderma.2010.05.012

[12] Knowles, O.A., Robinson, B.H., Contangelo, A. and Clucas, L. (2011) Biochar for the Mitigation of Nitrate Leaching from Soil Amended with Biosolids. Science of the Total Environment, 409, 3206-3210. http://dx.doi.org/10.1016/j.scitotenv.2011.05.011

[13] Clough, T., Condron, L., Kammann, C. and Müller, C. (2013) A Review of Biochar and Soil Nitrogen Dynamics. Agronomy, 3, 275-293. http://dx.doi.org/10.3390/agronomy3020275

[14] Biederman, L.A. and Harpole, W.S. (2013) Biochar and Its Effects on Plant Productivity and Nutrient Cycling: A Meta-Analysis. GCB Bioenergy, 5, 202-214. http://dx.doi.org/10.1111/gcbb.12037

[15] Abbasi, M.K., Hina, M. and Tahir, M.M. (2011) Effect of Azadirachta indica (Neem), Sodium Thiosulphate and Calcium Chloride on Changes in Nitrogen Transformations and Inhibition of Nitrification in Soil Incubated under Laboratory Conditions. Chemosphere, 82, 1629-1635. http://dx.doi.org/10.1016/j.chemosphere.2010.11.044

[16] Rondon, M., Ramirez, J.A. and Lehmann, J. (2005) Greenhouse Gas Emissions Decrease with Charcoal Additions to Tropical Soils. 3rd USDA Symposium on Greenhouse Gases and Carbon Sequestration in Agriculture and Forestry, Baltimore, 21-24 March 2005.

[17] Lehmann, J., Kern, D.C., Glaser, B. and Woods, W.I., Eds. (2004) Management. Kluwer Academic Publishers, New York.

[18] Kuzyakov, Y., Subbotina, I., Chen, H., Bogomolova, I. and Xu, X. (2009) Black Carbon Decomposition and Incorporation into Soil Microbial Biomass Estimated ${ }^{14} \mathrm{C}$ Labeling. Soil Biology and Biochemistry, 41, 210-219. http://dx.doi.org/10.1016/j.soilbio.2008.10.016

[19] Shin, J.D., Lee, S.I., Park, W.K., Choi, Y.S., Hong, S.G. and Park, S.W. (2014) Carbon Sequestration in Soil Cooperated with Organic Composts and Bio-Char during Corn (Zea mays) Cultivation. Journal of Agricultural Chemistry and Environment, 3, 151-155. http://dx.doi.org/10.4236/jacen.2014.34018

[20] Shin, J.D. (2014) Nitrogen Transformation in Soil Cooperated with Organic Composts and Bio-Char during Corn (Zea mays) Cultivation. Journal of Korea Organic Resources Recycling Association, 22, 33-40.

[21] Choi, Y.S., Shin, J.D., Lee, S.I. and Kim, S.C. (2015) Adsorption Characteristics of Aqueous Ammonium Using Rice Hull-Derived Biochar. Journal of Agricultural Environment, 34, 1-6. 